\title{
META-ANALISIS TENTANG PERILAKU KOPING PREVENTIF DAN STRES
}

\author{
Ahmad Muhammad Diponegoro \\ 8 \\ Syamsul Bachri Thalib \\ Universitas Negeri Makassar
}

\begin{abstract}
This meta-analysis study focused on preventive coping and stress. individual's study donit shows the result that not always consistent and sometimes contradict each other. So, it is difficult to get the inclusive and integrative conclusion.

The purpose of this study is to integrate the results of the study that varied about the relation between proventive coping and stres through meta analysis procedure. The subject analy sis contained 15 studies that consist 2816 sample size. The result of this study reveals that (a) there is a relation between preventive coping and stres (tho $=-0,363$, interval conlidence $95 \%=-0,02<p<0,74)$; (b) variance due to sampling error $=$ $0,0043(15,09 \%)$; (c) variance due to variation of reliability $=0,0012$ $(4,18 \%)$. This meta-analysis support conclution in the current literatur. The relation belween preventive coping and stress became consistence if we consider the research artilact, either the amount of the sample. subject characteristics of research instruments.
\end{abstract}

Key words: meta-analisis, penlaku koping preventif, dan stres

\section{PENDAHULUAN}

$\mathbf{P}$ embahasan tentang stres dan cara mengatasinya (coping) dalam disiplin psikologi, hingga saat ini, nampaknya belum sunt bahkan semakin meningkat. Hal ini tidak saja karena lingkungan kehidupan yang semakin memburuk tetapi juga karena semakin kompleksnya permasalahan dalam era globalisasi dewasa ini (Adisubrata, 1999).

Penelitian tentang stres yang muncul dalam jurnal profesional nampak semakin spesifik. Hal ini berkaitan dengan keadaan masyarakat yang semakin kompleks dan berbagai persoalan yang mereka hadapi. Berbagai penyakit yang berkaitan dengan stres juga cenderung meningkat, seperti tekanan darah tinggi, serangan jantung. beberapa jenis kanker dan sebagainya. Upaya penanggulangan dengan berbagai tehnik diupayakan dan teiah diujicobakan dalam berbagai penelitian (Rice, et al.. 1992).

Pad a dasamya penelitian secara umum dilakukan sebagai upaya menemukan kebenaran ilmiah yang sifatnya obyektif. dapat divenfikasi dan dapal dikomunikasikan 
melalui pendekatan ilmiah, tak terkecuali penelitian terhadap stres. Untuk dapat memenuhi fungsi ilmiah tersebut, maka diperkukan upaya untuk mengintegrasikan temuan-temuanatau hasil-hasil penelitian dengan cara yang logis, sistematis dan terarah (Hunter dan Schmidt, 1990).

Penelitian individual ternyata menunjukkan kelemahan atau keterbatasan sehingga menimbulkan variasi hasil antar penelitian. Hasil-hasil penelitian mengenai topik yang sejenis dari berbagai studi kadang-kadang tidak selalu searah bahkan mungkin berseberangan antara satu dengan lainnya sehingga memerlukan suatu analisis yang lebih komprehensif baik untuk pengintegrasian maupun untuk penerapan dan pengembangan teori.

Prosedur statistik kuantitatif dalam metaanalisis dilakukan untuk mengintegrasikan hasil penelitian dan mengoreksi artifakartifak penelitian yang berdampak pada vanasi hasil-hasil penelitian. Pendekatan ini pula diterapkan dalam menganalisis tentang hubungan antara koping preventif dan stres dari berbagai penelitian individual yang telah dipublikasikan. Melalui kajian ini diharapkan dapat memberikan kontribusi bagi pengembangan disiplin psikologi, khususnya psikologi klinis.

\section{PERILAKU KOPING PREVENTIF}

Bila ada sesuatu tekanan ałau persoalan. tiap individu selalu memberikan respon. Respon tersebut dapat berupa reaksi negatif, seperti yang diperlihatkan oleh bentukbentuk tingkah laku neurotisdan patologis. dan dapat berupa reaksi positif, seperti diperlihatkan dengan bentuk-bentuk penyesuajan diri yang sehat dan cara-cara pengatasan masalah yang konstruktif (Lazarus, 1976). Pengertan koping yang dipergunakan dalam penelitian ini adalah suatu bentuk tingkah laku individu untuk melindungi diri dari tekanan- tekanan psikologis, yang ditimbulkan oleh problematika pengalaman sosial (Pearlin \& Schooler, 1976).

Menurut fungsinya, tingkah laku koping dapat dibedakan menjadi dua yaitu koping yang terpusat pada masalah (problem focused coping $=$ PFC) dan koping yang terpusat pada emosi (emotional focused cooping $=\mathrm{EFC}$ ). PFC merupakan usaha individu, untuk mengurangi atau menghilangkan stres dengan cara menghadapi masalah yang menjadi penyebab timbulnya stres secara langsung. Selanjutnya EFC merupakan usaha-usaha individu untuk mengurangi atau menghilangkan stres yang dirasakannya tidak dengan menghadapi secara langsung tetapi lebih pada usaha untuk mempertahankan keseimbangan afeksinya (Fokman \& Lazarus, 1980).

Tingkah laku koping yang termasuk of dalam PFC (Aldwin \& Revenson, 1987) dapat dilakukan dalam bentuk: (a) sikap kehati-hatian (cautiousness), yaitu individu memikirkan dan mempertimbangkan secara matang beberapa alternatif pemecahan masalah yang mungkin, meminta pendapat dan pandangan dari orang lain tentang masalah yang dihadapinya, bersikap hatihati sebelum memutuskan sesuatu; dan (b) mengevaluasi strategi-strategi yang pernah dilakukan yang meliputi tindakan individu untuk menyelesaikan masalah secara langsung, serta menyusun rencana dan usaha-usaha yang ditujukan kepada orang lain yang terlibat atau meniadi penyebab masalah untuk kemudian menyelesaikan masalahnya.

Selanjutnya strategi yang termasuk Kategori EFC dapat dipilah menjadi empat jenis: (a) pelarian dari masalah (escapism), yaitu individu menghindari masalah yang ada dengan cara berkhayal dan atau membayangkan seandainya ia berada pada situasi dan saal lain yang lebih menyenangkan, menghindari memikirkan masalah 
dengan makan dan tidur lebih banyak, tidak merokok atau minum minuman keras; (b) pengurangan beban masalah (minimization), yaitu usaha individu untuk menolak masalah yang ada dengan cara menganggap seolah-olah masalah itu tidak ada; (c) penyalahan diti sendiri (se/f blame), yaitu individu cenderung menyalahkan diri sendiri, serta menyesall apa yang telah terjadi; (d) pencarian arti (seeking meaning), yaitu individu berusaha mencari arti kegagalan yang dialaminya bagi dirinya, serta melihat pada seginsegi yang dipentingkan dalam hidupnya (Aldwin \& Revenson, 1987).

Strategi-strategi koping preventif merupakan cara-cara yang umum digunakan oleh individu dalam menghadapi masalah, yang penggunaannya dapat secara bergantian atau dikombinasikan dalam menghadapi suatu masalah. Proporsi penggunaan kedua strategi ini relatif bervariasi tergantung pada bagaimana penilaian individu terhadap situasi yang sedang dihadapinya (Folkman \& Lazarus, 1980). Pada umumnya jika individu menilai situasi yang dihadapinya dapat dikendalikan dan diatașinya maka ia cenderung menggunakan PFC, tetapi jika individu merasa tidak mampu serta tidak berdaya menghadapi situasi yang ada, maka dia cenderung menggunakan bentuk EFC (Coyne, et al, 1981; Fleming, et al, 1984).

\section{MODEL-MODEL PERILAKU KOPING DAN STRES}

Matheny (dalam Rice, 1992) menyarankan dua jenis model koping, yaitu combative coping dan preventive coping. Upaya melakukan perlawanan (combative coping) terjadi tatkala stresor merangsang suatu reaksi dan muncul suatu usaha untuk mengurangi stresor. Disamping itu, upaya pencegahan st res (preventive coping), dapat dilakukan melałui strukturisasi penyusunan kognitif yang menimbulkan persepsi permintaan atau lewat peningkatan resistensi terhadap stres. Model combative coping mempelajari cara untuk melepaskan dii dari stres dengan melakukan perlawanan. sedang koping preventif merupakan tindakan belajar untuk menghindari stres dengan pencegahan. Selanjutrya Matheny membedakan tigajenis strategi koping preventif, yaitu: (a) mencegah stresor lewat penyesuaian kehidupan, penyebab timbulnya stres dan mengembangkan sumber-sumber koping. Penyesuaian tingkat permintaan berarti bahwa kebutuhan harus sesuai atau cocok dengan kemampuan yang dimiliki seseorang.

Upaya mengubah pola-pola prilaku penimbul stres dilakukan dengan cara-cara: (a) memodifikasi pola prilaku, (b) mengurangi sikap-sikap impulsif atau hiperaktif, dan (c) mengembangkan sumber-sumber koping temasuk membangun etikasi diri (self efficacy), harga diri (self-esteem), optimisme, religiusitas, dukungan sosial, control diri (bous of cortrol) dan ketrampilan pengelolaan diri.

Selanjutnya Matheny (dalam Rice. 1992) menyarankan periunya memonitor stres, mengelola dan menyusun suatu usaha koping yang efektit untuk memulai penggunaan strategi-strategi koping secara tepat. Hal ini mungkin melibatkan penggunaan kemampuan-kemampuan pemecahan masalah, pencarian informasi, kemampuan-kemampuan sosial, respons positif dan mengubah pola-pola hipereaktivitas. Seseorang dapat mengubah struktur kognitif guna mencegah asumsi-asumsi pembatasan diri yang mengganggu untuk memindahkan pemikiran-pemikiran yang mengalahkan diri, dan tetap terbuka terhadap pilihan-pilihan yang cocok.

Lebih jauh lagi, stres merupakan istilah yang sudah sering terdengar hampir dan menjadi pokok bahasan disegala bidang 
kehidupan. Pengertian stres menunjukkan variasi antara ahli yang satu dengan ahli yang lainnya. Folkman \& Lazarus (1988) mendefinisikan stres sebagai suatu akibat dari interaksi antara seseorang dengan lingkungannya yang dinilai membahayakan dirinya.

Senada dengan pendapat Lazarus, Gibson (dalam Yanto, 1992) mendefinisikan stres sebagai interaksi antara stimulus dan respon. Stres sebagai stimulus adalah kekuatan atau dorongan terhadap individu yang menimbulkan reaksi ketegangan atau menimbulkan perubahan-perubahan tisik individu. Stres sebagai respon yaitu respon individu baik respon yang bersifat fisiologik maupun respon yang bersifat psikologik, terhadap stresor yang berasal dari lingkungan. stresor tersebut merupakan peristiwa atau situasi dari luar yang bersifat mengancam individu. Juga Evans (1982) mengartikan stres sebagai suatu situasi yang memiliki karakteristik adanya tuntutan lingkungan yang melebihi kemampuan individu untuk mer espon. Lingkungan dalam pengertian ini tidak hanya menyangkut lingkungan fisik saja tetapi juga lingkungan sosial.

Baum (dalam Evans, 1982) menekankan proses interpretasi kognitif sebagai penyebab teriadinya stres. Interpretasi terhadap kondisi lingkungan memang mempengaruhi kondisi psikologik individu, sebagaimana diungkapkan oleh Lazarus (dalam Evans. 1982) bahwa individu tidak akan merasakan suatu kejadian itu sebagai suatu gangguan, bila stresor itu dinterpretasikan sebagai hal yang wajar.

Secara singkat dapat dirumuskan bahwa stres adalah suatu keadaan psikologik yang tidak menyenangkan yang disebabkan adanya interpretasi kognitif dan penilaian adanya ancaman, karena ketidakseimbangan antara tuntutan dan kemampuan diri individu dalam menghadapi tuntutan itu.

\section{HIPOTESIS}

Berdasarkan kajian teori dan telaah terhadap hasil-hasil penelitian individual tentang perilaku koping preventif dan stres, maka dalam penelitian ini hipotesis yang diajukan adalah: "ada hubungan metaanalisis antara perilaku preventif koping dengan stres".

\section{METODE PENELITIAN}

\section{Pendekatan}

Penelitian ini menggunakan pendekatan meta-analisis korelasi. Hunter \& Schmidt (1990; 1994) menegaskan bahwa metaanalisis korelasi mengacu pada upaya merangkum studi-studi korelasi yang relevan dan mengintegrasikannya menjadi variabel tertentu yang menghubungkan antara masing-masing penelitian untuk menarik konklusi umum mengenai suatu pokok permasalahan.

Analisis dalam meta-analisis didasarkan pada ketersediaan informasi artifak dari setiap studi untuk menyajikan artifak-artifak yang dapat dikoreksi. Kebanyakan studi hanya menginformasikan beberapa artifak tertentu saja informasi sebagian artifak ada pada beberapa studi, dan informasi lainnya ada pada studi-studi yang lain. Sekalipun demikian, meta-analisis dapat dilakukan dengan cara menggunakan distribusi efek artitak yang dikumpulkan dari berbagai studi dengan mengabaikan fakta bahwa ada salah satu atau beberapa artifak yang informasinya tidak tersedia pada setiap studi.

Hunter dan Schmidt (1990) menjelaskan bahwa artifak-artifak yang mengubah besarnya korelasi hasil penelitian dalam perbandingan terhadap korelasi aktual adalah: (a) kesalahan pengambilan sampel, (b) kesalahan pengukuran baik pada variabel dependen maupun variabel independen, (c) dikotomisasi pada variabel dependen dan 
atau variabel independen, (d) vanasi range dalam variabel dependen dan variabel independen, (e) ketidaksempurnaan validitas kontruk pada variabel dependen dan variabel independen, (f) kesalahan pelaporan atau transkripsional, dan (g) varians yang disebabkan oleh faktor-faktor luar.

\section{Kriteria dan seleksi data penelitian}

Krițeria seleksi data dalam penelitian ini adalah hasil-hasil penelitian individual yang memuat artifak-artifak yang dapat dikoreksi dengan mengacu kepada: (a) hasil-hasil penelitian korelasional tentang perilaku koping preventif dan stres, (b) dasar kemutakhiran dan akurasi data.yakni hasil penelitian yang dipublikasikan pada periode 1900-1999, (c) koping preventif merupakan variabel independen sedangkan stres sebagai variabel dependen.

Perigumpulan data dilakukan dengan cara menelusuri jurnal dan skripsi baik secara manual maupun melalui perangkat komputer. Berdasarkan kriteria dan karakteristik data yang relevan dengan permasalahan penelitian, maka ditemukan sebanyak 15 studi dari 13 peneliti yang memuat artifak yang dapat dikoreksi dalam meta-analisis. Lokasi penelitian individual mencakup penelitian-penelitian yang telah dilaksanakan diberbagai negara, termasuk Indonesia, dengan subyek yang juga bervariasi (siswa/ mahasiswa dan karyawan).

\section{Anailsis data}

Tekniik anailisis data yang oigunakan dalam penelitian ini mengikuti prosedur meta-arıalisis korelasi Hunter-Schmidt (1990). Berdasarkan ketersediaan informasi dari hasil-hasil penelitian individual, maka artifak-artifak yang dikoreksi mencakup kesatahan pengambilan sampel dan kesalahan pengukuran baik pada variabel dependen maupun kesalahan pengukuran pada variabel dependen.

Analisis korelasi meliputi langkahlangkah sebagai berikut:

1. Menghitung rerata korelasi dengan melakukan pembobotan, varians korelasi, kesalahan varians, dan varians terkoreksi.

2. Menghitung rerata gabungan; $A=$ Ave (a) Ave (b).

3. Menghitung korelasi studi yang dikoreksi; $(\rho)=$ Ave $\left(\rho_{i}\right)=$ Ave $(r) /$ A.

4. Menghitung jumlah kuadrat koefisien varians; $\mathrm{V}=\mathrm{SD}^{2} / \mathrm{Ave}^{2}$.

5. Merighitung varians yang disebabkan oleh varisi artifak; $\mathrm{S}^{2} 2=\rho^{2} A^{2} \mathrm{~V}$.

6. Menghitung varians korelasi yang sebenarnya, $\rho=\left[\operatorname{Var}(\rho \circ)-\rho^{2} A^{2}\right] / A^{2}$.

7. Menghitung interval kepercayaan.

8. Menghitung dampak kesalahan pengambitan sampel, variasi reliabilitas variabel dependen dan variasi reliabilitas variabel independen.

Kesimpulan hasil analisis didasarkan pada hasil perhitungan interval kepercayaan darl perhitungan dampak kesalahan pengambilan sampel serta variasi reliabilitas pengukuran baik pada variabel dependen maupun variabel independen.

\section{HASIL PENELITIAN}

\section{Deskripsi Data Penelitian}

Meta-araatisis ini terfokus pada 15 studi korelasi tentang koping-koping dalam kaitanriya dengan stres. Adapun hasil identifikasi topik-topik penelitian yang retevan dengan variabel analisis dapat dilihat pada tabel $i$ berikut ini. 
Tabel 1

Identifikasi Toplk Penelitlan

\begin{tabular}{|c|c|c|c|}
\hline No. & Nama & Tahun & Judul \\
\hline 1 & Muh Jamaludin & 1995 & Religiusitas dan stres kerja pada polisi \\
\hline 2 & E.L. Widuri & 1995 & Hubungan antara religiusitas dengan stres mahasiswa \\
\hline 3 & Erny Hidayati & 1995 & $\begin{array}{l}\text { Hubungan antara dukungan sosial dan harga diri dengan } \\
\text { stres kerja guru di Kecamatan Wirobrajan Yogyakarta }\end{array}$ \\
\hline 4 & A.D.I. Condrowidjojo & 1999 & Hubungan antara efikasi diri dan stres kerja \\
\hline 5 & Santiari & 1990 & Hubungan antara locus of control dan stres kerja \\
\hline 6 & Anon Susilo Hadi & 1996 & $\begin{array}{l}\text { Hubungan antara pusat kendali dan komitmen kerja } \\
\text { dengan stres kerja pada perawat di RSU Kardinah Tegal }\end{array}$ \\
\hline 7 & M.L. Putri Darmadji & 1996 & $\begin{array}{l}\text { Hubungan antara optimisme dan dukungan sosial } \\
\text { dengan stres pada siswa sekolah penerbang TNI AU DIY }\end{array}$ \\
\hline 6 & $\begin{array}{l}\text { V. Thanh, T.L. } \\
\text { Chatters \& Roosevelt }\end{array}$ & 1991 & Stres, psychological resources and subjective well being \\
\hline 9 & $\begin{array}{l}\text { V. Thanh, Than L } \\
\text { Chatters \& Roosevelt }\end{array}$ & 1991 & Stres, psychological resources and subjective well being \\
\hline 10 & Febrien Kumia & 1996 & $\begin{array}{l}\text { Dukungan sosial, kepercayaan diri, lama kerja dan stres } \\
\text { guru SD d DIY }\end{array}$ \\
\hline 11 & $\begin{array}{l}\text { Daniel W. Russell } \\
\text { Carolyn E Cutrona }\end{array}$ & 1991 & $\begin{array}{l}\text { Social support, stres, and depressive symtoms anong } \\
\text { elderly, test of aprocess }\end{array}$ \\
\hline 12 & $\begin{array}{l}\text { Kathryn H. Short } \\
\text { and Charlotte Jonston }\end{array}$ & 1997 & $\begin{array}{l}\text { Stres, matemal distres, and children adjusment following } \\
\text { immigration. The buffering role ot social support }\end{array}$ \\
\hline 13 & Catherine Cozzarell & 1993 & $\begin{array}{l}\text { Personality and self-efficacy as predictor of coping with } \\
\text { abortion }\end{array}$ \\
\hline 14 & Kivimaki & 1997 & $\begin{array}{l}\text { Psychosocial factors predicting employee sickness } \\
\text { absence during economic decline }\end{array}$ \\
\hline 15 & Catherine Cozzarell & 1993 & $\begin{array}{l}\text { Personality and self-efficacy as predictors of coping with } \\
\text { abortion }\end{array}$ \\
\hline
\end{tabular}


Karakteristik data selengkapnya dapat

dilihat pada tabel 2 berikut ini.

Tabel 2

Karakteristik Data dan Artifak Penelitian

\begin{tabular}{|c|c|c|c|c|c|c|}
\hline No. & Nama & Tahun & Variabel & $N$ & $r_{\mathrm{sm}}$ & $r_{v y}$ \\
\hline 1 & Jamaludin & 1995 & Religiusitas - Stres Kerja & 12 & 0,953 & 0,845 \\
\hline 2 & E.L. Widuri & 1995 & Religiusitas - Stres & 106 & 0,271 & 0,948 \\
\hline 3 & Erny Hidayati & 1995 & $\begin{array}{l}\text { Dukungan Sosial Harga } \\
\text { Diri - Stres Kerja }\end{array}$ & 74 & 0,875 & 0,863 \\
\hline 4 & A.D. Condrowidjojo & 1999 & Efikasi Diri - Stres Kerja & 89 & 0,971 & 0,976 \\
\hline 5 & Santiari & 1990 & $\begin{array}{l}\text { Locus of Control } \\
\text { Job Stres }\end{array}$ & 44 & 0,976 & 0,75 \\
\hline 6 & A.S. Hadi & 1990 & $\begin{array}{l}\text { Pusat Kendali } \\
\text { Komitmen Keria } \\
\text { Stres Kerja }\end{array}$ & 128 & 0,897 & 0,894 \\
\hline 7 & M.L.P. Darmadji & 1996 & $\begin{array}{l}\text { Optimisme } \\
\text { Dukungan Sosial - Stres }\end{array}$ & 44 & 0,885 & 0,953 \\
\hline B & L. Chatters & 1991 & Efikasi - Stres & 407 & 0,66 & \\
\hline 9 & L. Chatlers & 1991 & Self - Esteem - Stres & 407 & 0.58 & \\
\hline 10 & F. Kurnia & 1996 & $\begin{array}{l}\text { Dukungan Sosial } \\
\text { Kepercayaan Diri } \\
\text { Lama Kerja - Stres Kerja }\end{array}$ & $1 \uparrow 8$ & 0,894 & 0,92 \\
\hline 11 & $\begin{array}{l}\text { D.W. Russell \& } \\
\text { C. E. Cutrona }\end{array}$ & 1991 & Sosial Support - Stres & 301 & & \\
\hline 12 & $\begin{array}{l}\text { K.H.Short } \\
\& \text { C. Jonston }\end{array}$ & 1997 & Dukungan Sosial - Stres & 97 & 0,94 & 0,66 \\
\hline 13 & C. Cozzarell & 1993 & Self - Esteem - Stres & 112 & & \\
\hline 14 & Kivimaki & 1997 & Socia! Support - Stres & 763 & 0,93 & \\
\hline 15 & C. Cozzarell & 1993 & Efikasi Diri - Stres & 117 & & \\
\hline & Jumtah & & & 2407 & & \\
\hline
\end{tabular}


Pada tabel 2 di atas dapat dilihat karakteristik data penelitian yang memuat artifak-artifak yang dapat dikoreksi. Berdasarkan ketersediaan informasi dari data tersebut, maka artifak yang dapat dikoreksi meliputi 3 (tiga) komponen, yaitu: (a) kesalahan pengambilan sampef, (b) kesalahan pengukuran pada variabel dependen, dan (c) kesalahan pengukuran pada variabel independen. Dengan demikian, artifak-artifak lainnya yang menyebabkan variasi hasil-hasil penelitian lidak dapat dikoreksi karena keterbatasan informasi artifak, seperti validitas konstruk, variabel dependen dan independen, variasi rentang pada variabel independen, data dikotomi pada variabel dependen dan independen serta artifak atrisi.

Selanjutnya dilakukan perhitungan awa terhadap artifak-artifak yang akan dikoreksi, kesalahan pengukuran pada variabe dependen dan kesalahan pengukuran pada variabel dependen sebagaimana tertera dalam lembar kerja meta-analisis.

\section{Tabel3}

Lembar Kerja Meta-Analisis

\begin{tabular}{|c|c|c|c|c|c|c|c|}
\hline No. & Peneliti & $f_{x x}$ & a & $r_{y y}$ & $b$ & $N$ & $r_{x y}$ \\
\hline 1 & Jamaludin & 0.953 & 0,976 & 0,845 & 0,910 & 12 & $-0,43$ \\
\hline 2 & Widuri & 0,271 & 0,521 & 0,948 & 0,974 & 106 & $-0,473$ \\
\hline 3 & Hidayati & 0,875 & 0,935 & 0,863 & 0.929 & 74 & $-0,37$ \\
\hline 4 & Diah & 0,971 & 0,985 & 0,976 & 0,988 & 89 & $-0,574$ \\
\hline 5 & Santiari & 0,976 & 0,988 & 0,75 & 0,866 & 44 & $-0,641$ \\
\hline 6 & Hadi & 0,897 & 0,947 & 0,894 & 0,946 & 128 & $-0,613$ \\
\hline 7 & Maya & 0,885 & 0,941 & 0,953 & 0,976 & 44 & $-0,303$ \\
\hline 8 & Linda & 0,66 & 0,812 & & 0 & 407 & $-0,394$ \\
\hline 9 & Linda & 0,58 & 0,762 & & 0 & 407 & $-0,234$ \\
\hline 10 & Kurnia & 0,894 & 0,946 & 0,92 & 0,959 & 118 & $-0,403$ \\
\hline 11 & Russel & & 0 & & 0 & $30 \mathrm{t}$ & $-0,377$ \\
\hline 12 & Short & 0,94 & 0.97 & 0,66 & 0,812 & 97 & $-0,38$ \\
\hline 13 & Cozza rell & & 0 & & 0 & 112 & $-0,42$ \\
\hline 14 & Kivimaki & 0,93 & 0,964 & & 0 & 763 & $-0,096$ \\
\hline \multirow[t]{3}{*}{15} & Cozzarell & & 0 & & 0 & 112 & $-0,62$ \\
\hline & & $x$ & 0,896 & & 0,93 & 187,6 & $-0,442$ \\
\hline & & SD & 0,1731 & & 0,2764 & & $-0,054$ \\
\hline
\end{tabular}




\section{HASIL ANALISIS KUANTITATIF}

Berdasarkan langkah-langkah yang ditempuh dalam meta-analisis, maka hasil perhitungan studi kelompok 1 (studi no. 1 s.d 15), adalah sebagai berikut:

1. Hasil perhitungan reliabilitas terbobot variabel dependen $\left(r_{x x}\right)$ dan variabel independen $\left(r_{y y}\right)$ disajik an pada tabel 1 kolom a dan $\mathrm{b}$.

2. Hasil perhitungan rerata korelasi, varians korelasi, varians kesalahan, dan varians terkoreksi adalah sebagai berikut: (a) rerata korelasi, $r_{n}(r), r=\Sigma[N, r] / \mathbb{N}_{1}=$ 0,3188 ; (b) varians $r, S^{2} r\left(\sigma^{2}\right)$; $\Sigma\left[N_{i}(r-\right.$ r) $\left.)^{2}\right] / \Sigma N=0,0287$; (c) varians eror, $\left(\sigma^{2} \mathrm{e}\right)$ : $\left.\left(1-r^{2}\right)^{2} / N-1\right)=15\left(t--0,3188^{2}\right)^{2} / 15$ (186.6) $=0,00433$; (d) Varians terkoreksi atau varians yang sesungguhnya $\left(\sigma^{2}\right)$ : $\sigma^{2} p x y=\sigma^{2} r-\sigma^{2} \mathrm{e}=0,0288-0,00433=$ 0,024

3. Rerata gabungan: $A=$ Ave (a) Ave (b) $=$ $(0,896)(0,93)=0,833$

4. Korelasi studi yang dikoreksi $(\eta)=$ Ave (ri) $=$ Ave $(r) / A=-0,3188 / 0,83 / 0,83$ $=-0,383$

5. Jumlah kuadrat koefisien varians $(V)=$ $\mathrm{SD}^{2} /$ Ave $^{2}=0,1314^{2} / 0,896^{2}+0,054^{2} /$ $0,93^{2}=1,023$.

6. Vanans yang disebabkan oleh variasi artifak $\left(\mathrm{S}_{22}\right)=\rho^{2} A^{2} \mathrm{~V}$. $=\left(-0,383^{2}\right)\left(0,833^{2}\right)(0,0122)=0,00124$.

7. Varians korelasi yang sebenarnya, Var $(r)=[\operatorname{Var}(\rho 0)-\rho 2 A 2] / A 2$ $=(0,0245-0,00124) / 0,833=0,0335$. $S D(p)=\sqrt{0,0335}=0,183$.

8. Ințerval kepercayaan: $\mathrm{Mr}=\rho \pm 1,96(\mathrm{SD})$ $=-0,383 \pm 1,96(0,183)$

$=-0,383 \pm 0,3587$

$M p=-0,0243<\rho<-0,7417$

9. Dampak kesalahan pengambilan sampel, variasi reliabilitas pengukuran dan faktor lainnya yang tidak terspesifikasi. a. Dampak kesalahan pengambilan sampel, $(\sigma 2 e)=0,0028 / 0,0193 \times$ $100 \%=14,57 \%$

b. Dampak variasi reliabilitas, $(\mathrm{S} 22)=$ $0,000576 / 0,0193 \times 100 \%=3,36 \%$

c. Faktor lain yang tidak terspesifikasi adalah $0,0165-0,00057=0,0158$. Alau, $0,0158 / 0,0193 \times 100 \%=$ $82,01 \%$.

Berdasarkan perhitungan di atas, maka selanjutnya dapat dihitung dampak kesalahan pengambilan sampel, variasi reliabilitas, dan faktor lainnya yang tidak terspesifikasi.

a. Dampak kesalahan pengambilan sampel $(2 \mathrm{e})=0,0043$

b. Varians yang disebabkan oleh variasi reliabilitas $=0,00124$

c. Faktor lainnya adalah 0,0165 $0,00067=0,0158$

\section{SIMPULAN DAN SARAN}

\section{Simpulan}

Berdasarkan analisis atas ke 15 studi di atas maka dapat ditarik simpulan sebagai berikut:

1. Secara deskriptif hasil-hasil penelitian individual tentang koping preventif dan pengaruhnya terhadap stres menunjukkan hasil yang bervariasi. Hal ini disebabkan karena perbedaan karakteristik dari masing-masing studi, seperti subyek penelitian, prosedur pengambilan sampel, besarnya sampel, reliabilitas pengukuran, dan artifak-artifak lainnya.

2. Secara keseluruhan meta-analisis ini menunjukkan bahwa ada hubungan antara koping dengan stres, pada interval kepercayaan $95 \%$. Interval kepercayaan $95 \%$ adalah: $-0,024<\rho<-0,7417$ ). Ini berarti bahwa semakin tinggi koping preventit semakin rendah kemungkinan terjadinya gangguan stres. 
3. Ditemukan adanya dampak kesalahan pengambilan sampel, dampak variasi reliabilitas pada variabel independen dan variabel dependen serta faktor lainnya yang mempengaruhi variasi hasil studi individual.

\section{Saran}

1. Meta-analisis ini berfokus hanya pada 15 studi korelasi tentang koping preventif dengan stres. Karena itu disarankan kiranya dilakukan metaanalisis terhadap sampel yang lebih luas lagi sehingga memberikan gambaran yang lebih komprehensif tentang manfaat perilaku koping preventif terhadap stres.

2. Perlu pula dilakukan meta-analisis terhadap combalive coping sehingga hasilnya bisa dibandingkan dengan preventive coping untuk mengetahui masing-masing efektivitas diantara keduanya, atau dapat pula dilakukan secara bersamaan dalam kondisikondisi tertentu.

3. Kajian ini hanya mencakup hasil-hasil penelitian korelasional sehingga diperlukan meta-analisis yang didasarkan pada hasil-hasil penelitian eksperimen sebagai bahan perbandingan sejauhmana pengaruh koping preventif terhadap gangguan stres.

4. Meta-analisis ini didasarkan pada tiga artifak penelitian yaitu besarnya sampel, reliabilitas variabel dependen, dan reliabilitas variabel independen. Hal ini disebabkan karena kelerbatasan artifak pada studi-studi individual. Karena itu diperlukan analisis yang mencakup artifak-artifak yang lebih luas.

\section{KEPUSTAKAAN}

Adisubrata, D. (1999). Bahan Kuliah Program Doktor Psikologi (tidak diterbitkan), UGM. Yogyakarta.

Carson, P.P., Carson, D.K., Griffeth, R.W. \& Steel, R.P. (1994). Promotion and employee tumover: critique, meta-analysis, and implications. Joumal of Business and Psychology, 8 (4), 455-466.

Darwin, FW. (1990). Pilihan Strategi Koping berdasarkan tipe kepribadian A dan B. Skripsi. Fakultas Psikologi, UGM. Yogyakarta.

Folkman 8 Lazarus, R.S. (1980). An Analysis of coping in a middle-aged community sampel, Joumal of Health and Social Behavior, 19,219-239.

Folkman, S. \& Lazarus, R.S. (1988), Coping as a mediator of emotion, Journal of Personality and Psychology, 54, 466475.

Hall, C.S. \& Lindzey, G. (1985). Theories of Personality. New York: John Wiley \& Sons.

Hunter, J.E \& Schmidt, FL. (1990), Methods of Meta-Analysis: Correcting bias in re search findings. Newbury Park Califomia: Sage Publications.

Hunter, J.E. \& Schmidt, F.L. (1994). Estimation of sampling error variance in the meta-analysis of correlations: Use of average correlation in the homogeneous case. Joumal of Applied Psychology, 79 (2). $17 \uparrow-177$.

Lazarus, R.S. (1980). The trivialization of distres. Dalam Barborah Hammon and C James Scheier (Eds). Psychology of Health. Washington: APA Inc. 
Mc.Clelland, D.C. (1979). Inhibited power motivation and high blood pressure in men. Journal of Abnomal Psychology. 08, 182-190.

Nietzel, M.T., \& Berstein, D.A., (1987). Introduction of Clinical Psychology (2nd. ed), New Jersey: Prentice-Hall, Inc.

Fice Phillip, L (1992). Stres and Health. Beimont California: Brooks and Cole.

Fobinson, D.N. (1976). Psychology-tradition and perspectives. Melbourne: D. Van Nostrand Company.

Sarafino, E.P. (1990). Health Psychology: Biopsychosocial Interactrons. Canada: John Willey \& Sons inc.
Stone, A.P. \& Neale, J.M. (1984). New Measure of daily coping: development and preliminary research, Journal of Per. sonality \& Social Psychology. 46, 892906.

Wanous, J.P., Polland T.D., Premack, S.L., \& Davis, KS. (1992). The effect of met expectations on newcomer attitudes and behaviors: A review and meta-analysis. Journal of Applied Psychology. 77 (3), 288-297.

Watson, D.L., Gail de Bortoll-Tregerthan, Frank, J. (1984). Socral Psychology: Science \& Application. Illionis. 